\title{
Increased expression of EphA7 correlates with adverse outcome in primary and recurrent glioblastoma multiforme patients Lin-Fang Wang1,3, Emmanouil Fokas' ${ }^{1}$, Janko Juricko1, An You ${ }^{1}$, Frank Rose ${ }^{1}$, Axel Pagenstecher ${ }^{2}$, Rita Engenhart-Cabillic ${ }^{1}$ and Han-Xiang An*1
}

\author{
Address: ${ }^{1}$ Department of Radiotherapy and Radiation Oncology, Philipps-University Marburg, Baldingerstr. D-35043 Marburg, Germany, \\ ${ }^{2}$ Department of Neuropathology, Philipps-University Marburg, Baldingerstr. D-35043 Marburg, Germany and ${ }^{3}$ Department of Emergency Surgery, \\ Union Hospital, Tongji Medical College, Huazhong University of Science and Technology, 430030 Wuhan, People's Republic of China \\ Email: Lin-Fang Wang - wang@staff.uni-marburg.de; Emmanouil Fokas - fokas@med.uni-marburg.de; Janko Juricko - juricko@med.uni- \\ marburg.de; An You - youa@staff.uni-marburg.de; Frank Rose - rosef@med.uni-marburg.de; Axel Pagenstecher - pagenste@med.uni- \\ marburg.de; Rita Engenhart-Cabillic - engenhar@med.uni-marburg.de; Han-Xiang An* - an@med.uni-marburg.de \\ * Corresponding author
}

Published: 25 March 2008

BMC Cancer 2008, 8:79 doi:10.1/86/|47|-2407-8-79
Received: 8 August 2007

Accepted: 25 March 2008

This article is available from: http://www.biomedcentral.com/I47/-2407/8/79

(c) 2008 Wang et al; licensee BioMed Central Ltd.

This is an Open Access article distributed under the terms of the Creative Commons Attribution License (http://creativecommons.org/licenses/by/2.0), which permits unrestricted use, distribution, and reproduction in any medium, provided the original work is properly cited.

\begin{abstract}
Background: Malignant gliomas are lethal cancers, highly dependent on angiogenesis and treatment options and prognosis still remain poor for patients with recurrent glioblastoma multiforme (GBM). Ephs and ephrins have many well-defined functions during embryonic development of central nervous system such as axon mapping, neural crest cell migration, hindbrain segmentation and synapse formation as well as physiological and abnormal angiogenesis. Accumulating evidence indicates that Eph and ephrins are frequently overexpressed in different tumor types including GBM. However, their role in tumorigenesis remains controversial, as both tumor growth promoter and suppressor potential have been ascribed to Eph and ephrins while the function of EphA7 in GBM pathogenesis remains largely unknown.
\end{abstract}

Methods: In this study, we investigated the immunohistochemical expression of EphA7 in a series of 32 primary and recurrent GBM and correlated it with clinical pathological parameters and patient outcome. In addition, intratumor microvascular density (MVD) was quantified by immunostaining for endothelial cell marker von Willebrand factor (VWF).

Results: Overexpression of EphA7 protein was predictive of the adverse outcome in GBM patients, independent of MVD expression ( $P=0.02$ ). Moreover, high density of MVD as well as higher EphA7 expression predicted the disease outcome more accurately than EphA7 variable alone $(p=0.01)$. There was no correlation between MVD and overall survival or recurrence-free survival $(p>0.05)$. However, a statistically significant correlation between lower MVD and tumor recurrence was observed $(p=0.003)$.

Conclusion: The immunohistochemical assessment of tissue EphA7 provides important prognostic information in GBM and would justify its use as surrogate marker to screen patients for tyrosine kinase inhibitor therapy. 


\section{Background}

The incidence of brain tumors worldwide is about 7 in 100,000 per year $[1,2]$. Glioblastoma multiforme (GBM), the most aggressive tumor among malignant gliomas, is the most common primary brain tumor in adults and represents a significant source of cancer-related death. GBM usually recurs despite the most aggressive treatment via surgical resection of the tumor followed by radiation and/ or chemotherapy $[1,2]$. The poor prognosis of patients with GBM (median survival ranging from 9 to 12 months, 5 -year survival rate close to $0 \%$ ) mandates the exploration of novel molecular mechanisms that might contribute to the pathogenesis of this disease and its resistance to therapy with the purpose of therapeutic targeting [1-3].

Receptor tyrosine kinases (RTKs) are known to be important regulators of cellular growth controlling cell proliferation, differentiation and migration [4,5]. The Eph receptors and their ligands, ephrins, represent the largest known family of RTKs. Their role has been largely studied during the development of nervous system. They are involved in the development of central nervous system, including axon guidance, axon fasciculation, neural crest cell migration, hindbrain segmentation, vasculogenesis and neuronal cell survival during embryonic development [6-13]. Eph receptors and ephrin ligands are classified into A and B subfamily, on the basis of their sequence, homologies, structures, and binding affinities. EphA receptors bind the glycosylphosphatidylinositol (GPI)-anchored ephrin-A ligands, whereas EphB receptors bind the transmembrane ephrin-B ligands, whose cytoplasmic domain is capable to engage in various signaling activities; an exception is the EphA4 receptor that binds ephrin-B2 and ephrin-B3 as well as ephrin-A ligands [1416]. Moreover, these RTKs have the ability to induce both forward and reverse (bi-directional) signaling between adjacent interacting cells.

To date, various studies have investigated the involvement of the Eph-RTKs in several pathogenetic processes in the nervous system. EphB2 and ephrin-B2 signaling participate in the glial scarring process after spinal cord trauma [17]. The phosphorylation ratio of R-Ras was closely linked to the phosphorylation ratio of EphB2 in glioblastoma tissues [18]. Additionally, the phosphorylation ratio of EphB2 is an important mechanism that mediates glioma cell migration and invasion [19]. Ephrin-B2 and EphB4 were overexpressed by endothelial cells of human malignant gliomas [20]. Ephrin-B3 was also demonstrated as an important factor regulating glioma cell invasion through Rac1 GTPase [21]. EphA2 protein was overexpressed in GBM and anaplastic astrocytoma tissues and was identified as a novel target for the development of glioma vaccines [22,23]. Another group confirmed overexpression of EphA2 expression in GBM cells, proba- bly through decreased interaction between EphA2 receptor and its inhibitory ligand ephrin-A1 in malignant cells [19].

EphA7 (formerly known as Mdk1/Ebk/Ehk) is highly conserved in vertebrates from fish to human [24]. It is widely expressed in embryonic tissues, especially developing central nervous system [25]. EphA7 cooperates with other EphA receptors in cell signaling, but in contrast to other Eph receptors, it contains two developmentally regulated isoforms: a full-length version containing the intracellular tyrosine kinase domain and a truncated form that lacks this domain [26]. Immunoreactivity for the full-length wild type receptor is found in all cell populations expressing EphA7 mRNA in mouse embryo heads and developing brain, while the truncated EphA7 is absent in the embryos. Interestingly, both isoforms show striking distributions in adult mouse brain [27]. The full-length EphA7 is strongly expressed in neuropil; in contrast the truncated EphA7 is conspicuous on cell bodies and proximal dendrites of a limited number of neuronal types [28]. The truncated form of EphA7 acts as a dominant negative antagonist, suppressing tyrosine phosphorylation of the full-length EphA7 receptor and shifts the cellular response from repulsion to adhesion. Additionally, EphA7 is probably essential during closure of the neural folds, since EphA7-null mice displayed lack of the neural folds resembling anencephaly in man [29]. Moreover, EphA7 has been identified as an important molecular cue expressed after spinal cord injury, implicated in glial apoptosis [30]. Recent work indicated EphA7 as an important mediator of neural progenitor apoptosis during brain development [31]. However, little is currently known about its role in brain tumor angiogenesis and pathogenesis.

In the present study, we investigated the immunohistochemical expression of EphA7 and correlated it with clinical pathological parameters and tumor vascularity. We provide evidence that EphA7 is overexpressed in GBM and suggest that this receptor might be used as a new diagnostic and prognostic marker for further Eph/ephrin targeted molecular cancer therapy.

\section{Methods \\ Tissues}

Tumor samples of 32 patients with histologically confirmed GBM, WHO IV, (26 primary GBM, 6 recurrent GBMs and 10 normal brain samples) were obtained from the Department of Neuropathology, Marburg University Hospital, Germany. Approval for immunohistochemical study conduct in this GBM tissue bank had been obtained by the university authorities together with the signed consent of the patients. The patients underwent surgery and received adjuvant radiation therapy combined with chemotherapy using the schema ACNU and VM-26. The first 
follow-up occurred 6 weeks after therapy was completed. Subsequent follow-ups were scheduled every 3 months. In addition to clinical investigations and monitoring of indices of recurrence, a radiological examination was performed to detect possible relapses. Disease progression was defined according to WHO criteria by either an increase of at least $25 \%$ in tumor size or any new tumor identified by CT or MRI scan. Normal brain samples, which included cortex and white matter, were obtained from autopsy cases without any evidences of brain tumor or other brain disease. Totally, five cases of male and five cases of female (age ranging from 27 to 70 years, average: 48.6 years) were obtained.

\section{Immunohistochemistry}

Immunohistochemical studies were performed on formalin fixed, paraffin-embedded tissue. Samples slides were passed through a sequence of Roti-histol (Carl Roth, Karlsruhe, Germany) and graded alcohol and then rinsed in phosphate-buffered saline (PBS). After rinsing with PBS, the slides were treated with 3\% hydrogen peroxide in PBS for $15 \mathrm{~min}$ at room temperature in order to abolish endogenous peroxidase activity. Subsequently, the slides were treated with 5\% blocking serum for 1 hour. Following this, slides were incubated overnight at $4{ }^{\circ} \mathrm{C}$ with a rabbit anti-human EphA7 polyclonal antibody (H-55) against amino acids of human EphA7 (1:100 dilution; Santa Cruz Biotechonology, Heidelberg, Germany), or rabbit anti-human Factor VIII (von Willebrand Factor, vWF) polyclonal antibody (1:400 dilution; Dako Cytomation, Carpinteria, CA). In negative controls, the primary antibody was replaced with $1 \times$ PBS. The signal was enhanced by using biotinylated polyclonal goat-anti-rabbit IgG with streptavidin-HRP (Dako Cytomation, Carpinteria, CA) for 30 minutes. The colour was developed after 5 minutes incubation with 3,3-diaminobenzidine (DAB) solution and sections were weakly counterstained with hematoxylin for 10 seconds.

\section{Evaluation of EphA7 expression}

The membranous and cytoplasmic expression of EphA7 on tumor cells was assessed at a $\times 400$ magnification. The assigned score first reflects the staining intensity A $(0$, negative; 1 , weak; 2 , moderate; 3 , high) and second the percentage of positive cells B ( 0 , no positive cells; $1,<25 \%$ positive cells; 2,25 to $50 \%$ positive cells; $3,>50 \%$ positive cells). An overall score of 3 is defined as positive staining. The scoring was performed separately by two independent observers who were blinded to the clinical data. Any discrepancies were resolved on the conference microscope.

\section{Evaluation of MVD at "hot spot" of tumor angiogenesis}

Tumor angiogenesis can be reflected by MVD in the most vascularised areas of tumor tissue. MVD, as highlighted by factor VIII-related antigen immunostaining, was assessed without knowledge of the patient's clinical outcome, as described by Weidner et al [32]. Briefly, each slide was scanned at low magnification $(\times 100)$ to identify four areas with the highest density of microvessel (hot-spots). Each hot-spot was then evaluated at high power magnification $(\times 200)$ for the number of stained microvessels per field in a $0.7386 \mathrm{~mm}^{2}$ surface area. vWF-positive stained blood vessels with a complete lumen as well as cell clusters without lumina were considered as individual microvessels. The final microvessel score was the average of vessel counts from four fields assessed by a high power magnification field $(\times 200)$.

\section{Statistical analysis}

Survival curves were estimated using the Kaplan-Meier method. The distributions of survival were compared using the log rank test. The chi-square test was employed to determine the association between EphA7 expression intensity on tumor cells and MVD. A p-value $<0.05$ was considered to be statistically significant. All statistical analysis was performed using SPSS software.

\section{Results}

\section{Demographic factors}

32 patients with histologically confirmed primary and recurrent GBM, WHO grade IV, were studied. The mean age at diagnosis was 54.3 years (range 31-71). No significant difference in age distribution between male (21 cases) and female (11 cases) was detected. All of the 32 patients showed a relapse between 1 and 22 months after surgery and subsequently died of the disease (median survival 15 months).

EphA7 immunoreactivity in GBM and normal brain tissues In 22 of 32 patients, EphA7 immunoreactivity was observed on the prominent membrane and cytoplasm of tumor cells showing different intensities of EphA7 protein. Representative photomicrographs illustrating specimens with negative and strong EphA7 expression in tumor cells are presented in Fig. $1 \mathrm{~A}$ and $1 \mathrm{~B}$, respectively. EphA7 protein expression in glioma cells of 10 normal brain tissues analyzed was undetectable as it was shown in Fig. 1E. Of the $32 \mathrm{GBM}$ analyzed, strong expression of EphA7 (staining intensities of from 6 to 9) was observed in 14 cases $(43.7 \%)$ of GBM. The staining was specific in both tumor and endothelial cells, with minimal staining of surrounding connective tissues.

\section{EphA7 associated with MVD in GBM}

All tumors were stained with vWF and microvessels were counted as a measure of tumor's angiogenic activity. The median MVD of 30 vessels was treated as a cutpoint. High MVD was noted in areas where overexpression of EphA7 was marked (Table 1). Representative examples of low or high MVD were showed in Fig 1C and 1D, respectively. 

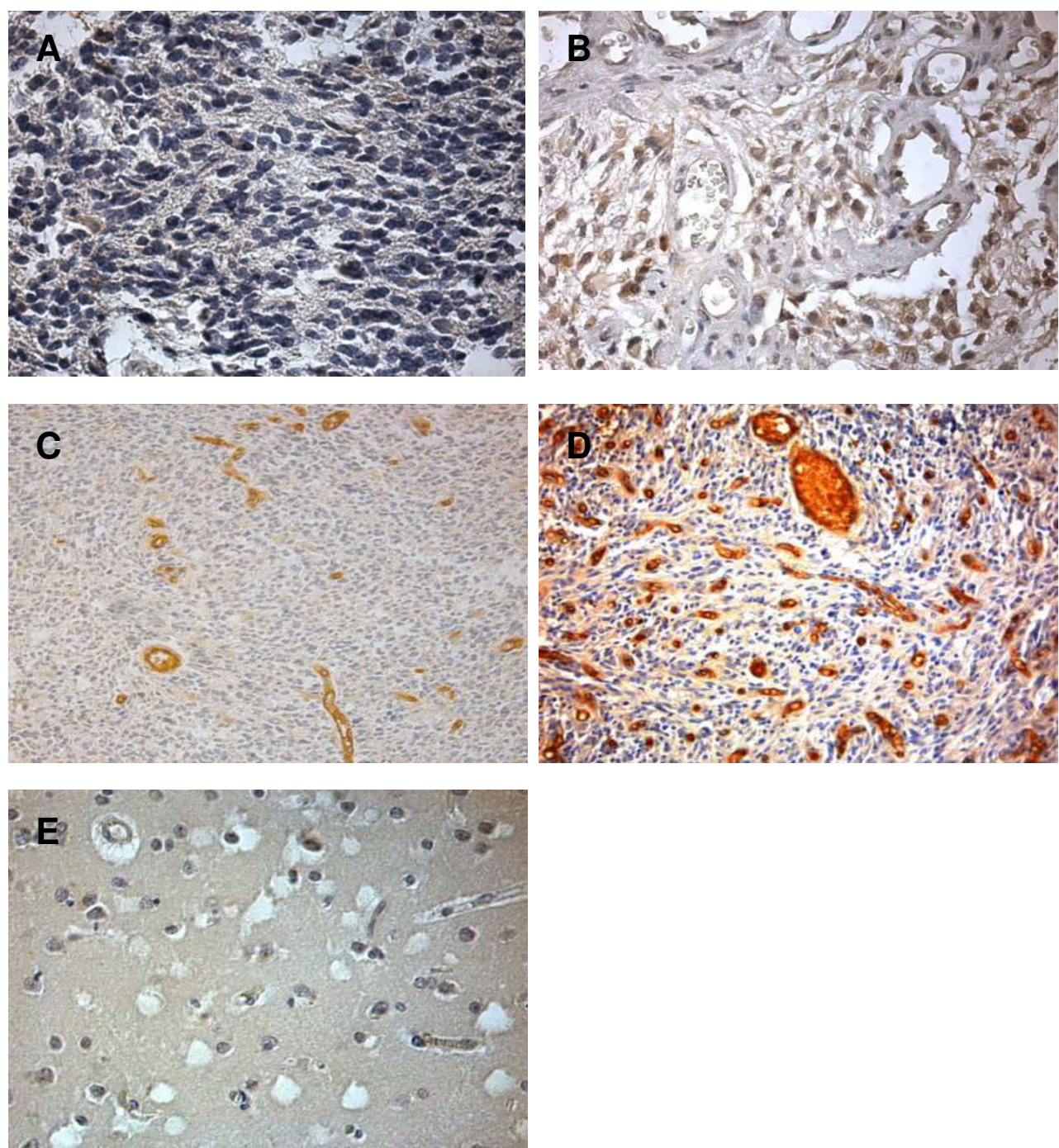

\section{Figure I}

Immunohistochemical demonstration of EphA7 protein expression and blood vessels in GBM. Representative examples of GBM showing negative staining in tumor cells $(A)$ or strong membranous and cytoplasmic staining in both tumor cells and endothelial cells (B). MVD in GBM by immunohistochemical staining for vWF, microvessels are represented by brown clusters, which stand out sharply from other tissues. Low tumor vascularity (C) in GBM with low expression of EphA7 as shown A. In contrast, microvessel density was relatively high (D) in GBM with high expression of EphA7 as shown B. Negative staining in normal brain tissue (E). Original magnification, $\times 400(A, B, E)$ and $\times 200(C, D)$.

There was a statistically significant correlation between expression of EphA7 and MVD in the tumors $(\mathrm{P}=0.004$, Table 1).

\section{EphA7 immunoreactivity predicted overall survival but not recurrence-free survival}

The median survival of patients with positive EphA7 expression was reduced in comparison with patients with negative EphA7 expression. EphA7 protein expression showed an inverse correlation with the overall survival ( $p$
$=0.02$, Fig. 2A). However, the level of EphA7 expression did not emerge as a prognostic factor for recurrence-free survival of GBM patients ( $\mathrm{p}=0.51$, Fig. $2 \mathrm{~B}$ ). There was no correlation between MVD and overall survival or recurrence-free survival ( $\mathrm{p}>0.05$, data not shown). We further explored the prognostic relationship using EphA7 in combination with MVD. The study cohort could be divided into 3 groups based on expression for EphA7 and MVD combination: EphA7 $(+) /$ high MVD $(n=12)$, EphA7 $(+) /$ low MVD $(n=10)$, EphA7 $(-) /$ high MVD $(n=0)$, EphA7(- 
Table I: Relationship between EphA7 expression and intratumor microvessel density in 32 primary and recurrent GBM.

\begin{tabular}{cccc}
\hline & EphA7 expression & P value \\
\hline MVD & negative & positive & \\
Low & 10 & 10 & \\
High & 0 & 12 & 0.004 \\
\hline
\end{tabular}

MVD: microvessel density, $\mathrm{N}$ : number of patients. The median MVD of 30 vessels was used as a cutpoint.

)/low MVD $(n=10)$. As shown in Fig. 2C, high density of MVD as well as EphA7 expression predicted for the disease outcome more accurately than Eph variable alone $(\mathrm{p}=$ $0.01)$.

\section{Clinical features associated with EphA7 or MVD}

Statistical correlation was detected between the expression levels of EphA7 or MVD and clinical pathological parameters such as age, gender and tumor status (Table 2). A statistically significant correlation between higher MVD and tumor recurrence was observed $(\mathrm{p}=0.003)$. In addition, positive EphA7 expression was associated with increased age of patients ( $>55$ years, $\mathrm{p}=0.003$ )

\section{Discussion}

There is currently an urgent need for development of alternative, effective diagnostic and therapeutic approaches to GBM. The survival of patients with GBM may depend on the identification of novel targets. EphA2 receptor has already been recognized as a potential molecular marker and target in GBM for the development of novel biological therapeutic agents $[22,23,33]$. Whereas several studies in recent years have clearly indicated that altered expression of Eph receptors and ephrin ligands is associated with increased potential for tumor growth, angiogenesis, metastasis and adverse outcome [34-42], few studies have addressed the role of EphA7 in tumor pathogenicity. By employing immunohistochemical techniques we have found that EphA7 protein is predictive for the outcome of patients with GBM, independent of MVD expression. The data in the present study revealed for the first time a strong correlation between EphA7 overexpression and patient survival.

Hafner C, et al. found that EphA7 is highly expressed in kidney vasculature [43]. The mRNA of EphA7 is strongly upregulated in hepatocellular carcinoma as compared with healthy liver tissue and is downregulated in colon carcinomas. EphA7 is also transcriptionally activated in lung cancer [44]. Furthermore, overexpression of EphA7 protein is frequently found in younger patients and in patients with advanced gastric carcinoma [45]. EphA7 expression is frequently silenced in human colorectal car- cinoma by aberrant promoter methylation [46]. EphA7 is located on $6 \mathrm{q} 16.1$, a region in close proximity to the chromosome 6 breakpoint found in various types of cancer [47]. Although our findings are not consistent with Wang et al, who found a significant downregulation of EphA7 in colorectal carcinoma [46], they are in line with previous reports reporting a tumor promoter role in lung cancer and hepatocellular carcinoma $[43,44]$, implicating tumor type-specific function for different Eph family members. Eph receptors expressed in different cell types may have opposite effects due to cell-type specific intracellular signaling pathway [4]. Indeed, EphB4 receptor has been identified as a tumor suppressor in breast cancer, through activation of Abl-Crk antioncogenic pathway [48], while the same receptor presented a tumorigenic potential in mesothelioma, favoring uncontrolled cell growth, migration, and tumor progression [49]. Moreover, membranebound ephrins trigger Eph receptor phosphorylation, while soluble forms can bind to Eph receptor, but do not trigger receptor activation [50]. Murine and human peripheral lymphocytes secrete a truncated form of EphA7 [51]. Truncated Eph receptors retaining their ligand-binding capacity have been shown to block activation of the full-length receptor [52]. Promoter hypermethylation and silencing of EphA7 in mature B-cell lymphomas may serve to eliminate the inhibitory activity of secreted EphA7 on tumor-promoting EphA7 receptor signaling, thus enhancing tumor cell spread and recruitment of accessory cells able to promote tumor growth [51]. A recent study on signaling pathways involved in EphA7 RTK reported that direct EphA7 knockdown can result in attenuation of ERK1/2 phosphorylation and induce apoptosis of leukemia cells, suggesting the impact of EphA7 on the growth of tumor cells [45]. It is of interest that positive EphA7 expression was closely associated with increased age of patients (>55 years). Whether this is a random finding or not deserves further investigation.

The unfavorable prognostic influence of EphA7 in GBM could be attributed to the well-recognised role of Eph RTKs in tumor angiogenesis. Indeed, in this study a statistically significant correlation between expression of EphA7 and MVD was noted in GBM specimens. Another important observation was EphA7 overexpression in both vasculature as well as tumor cells. The process of angiogenesis plays a central role in tumor growth and in the development of distant metastases by facilitating the entry of cells into circulation [52-55]. A vast biochemical and genetic evidence has implicated the critical role of Eph/ ephrin signaling in angiogenesis, despite of VEGFR2 and Tie2 receptors long been recognized as key players in this process [53,54]. Angiogenetic activity can be measured histologically by MVD, which has been shown to be an independent prognostic parameter in various malignancies including gliomas [56-58]. However, other studies on 

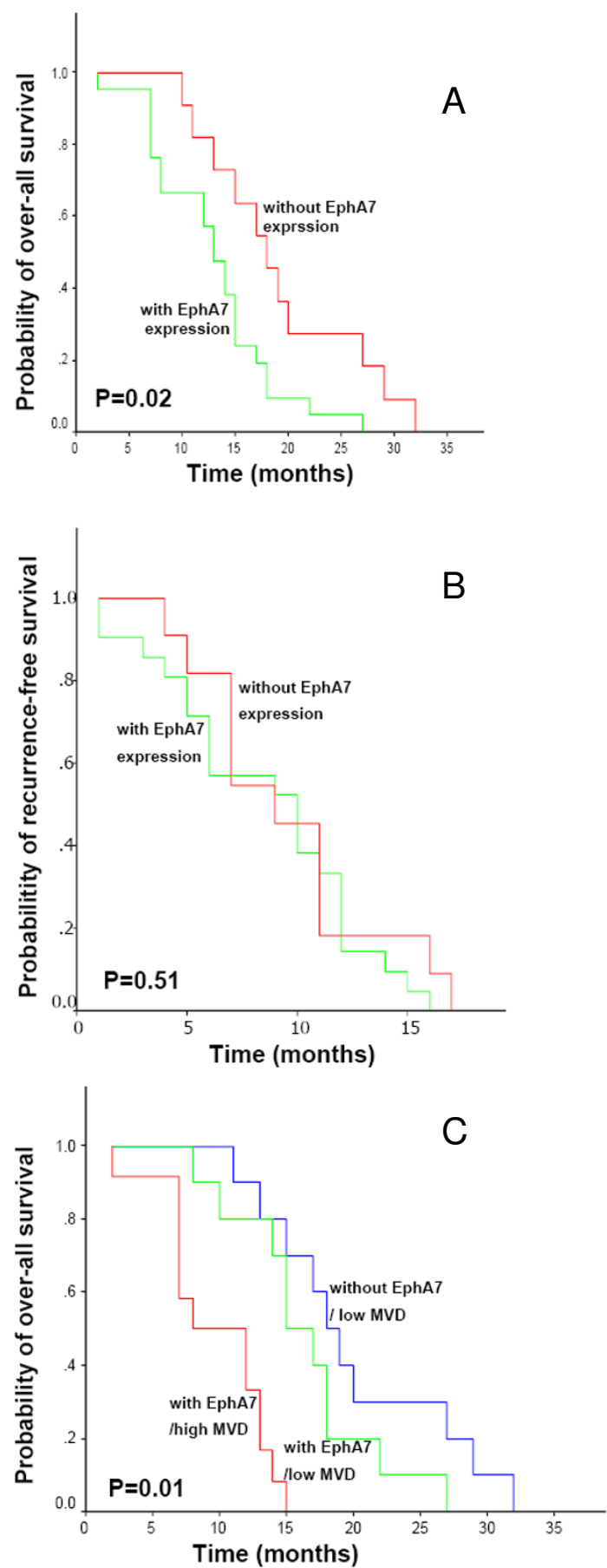

\section{Figure 2}

Kaplan-Meier curve for overall survival and recurrence-free survival in 32 patients based on EphA7 expression and MVD index. (A) Increased EphA7 expression was significantly associated with dead of disease ( $P=0.02$ by log-rank test), when positive EphA7 (score $=4-9$ ) expressing tumors were plotted against negative EphA7 expressing tumors (score $=0-3$ ). (B) EphA7 expression revealed no significance for recurrence-free survival. (C) EphA7 expression in combination with high MVD showed an inverse outcome $(p=0.01)$. 
Table 2: Relationship between EphA7 expression or microvessel count and clinicopathological features of 32 patients with GBM.

\begin{tabular}{|c|c|c|c|c|c|c|}
\hline \multirow[b]{2}{*}{ Age } & \multicolumn{2}{|c|}{ EphA7 expression } & \multirow[t]{2}{*}{$P$ value } & \multicolumn{2}{|r|}{ MVD } & \multirow[t]{2}{*}{$P$ value } \\
\hline & $\mathrm{N}$ & positive (\%) & & $\mathrm{N}$ & high MVD N (\%) & \\
\hline$<=50$ & 10 & $3(30)$ & & 11 & $6(54.55)$ & \\
\hline$>50$ & 22 & $19(86.36)$ & 0.003 & 21 & $16(76.19)$ & ns \\
\hline \multicolumn{7}{|l|}{ Gender } \\
\hline male & 21 & $15(7 \mid .43)$ & & 21 & $15(7 \mid .43)$ & \\
\hline female & 11 & $7(63.64)$ & ns & 11 & $8(72.72)$ & ns \\
\hline \multicolumn{7}{|l|}{ Tumor status } \\
\hline Primary & 26 & $20(76.92)$ & & 26 & $22(84.62)$ & \\
\hline Recurrence & 6 & $2(33.33)$ & ns & 6 & I (I6.67) & 0.003 \\
\hline
\end{tabular}

MVD: microvessel density, N: number of patients, ns: not significant. The median MVD of 30 vessels was used as a cutpoint.

angiogenesis of glioblastomas suggested the limited usage of MVD as prognostic parameter due to the complexity of the microvascular network in GBM [59,60]. Although no correlation between MVD and overall survival or recurrence-free survival was found in our study, we observed a statistically significant correlation between lower MVD and tumor recurrence. Further prospective studies with large numbers of patients are, however, needed to fully clarify the clinical implications of MVD in GBM recurrence.

\section{Conclusion}

Taken together, our data illustrated that EphA7 could be a potential candidate as a prognostic tumor marker and a new targeted therapeutic assessment in primary and recurrent GBM. Based on our findings, there might be a possible relationship between EphA7 and tumor neovascularization. Recent data demonstrating inhibition of angiogenesis through EphA receptor blockade in two different animal tumor models are consistent with our observation [52]. Additional experimental work is necessary to unveil the biologic pathway linking Eph/ephrins with tumor growth in cancer cells and tumor-associated vessels of GBM and further studies are needed before EphA7 becomes established as an important prognostic and predictive tool in GBM. Ultimately, specific EphA7 inhibitors may prove to be of therapeutic value.

\section{Abbreviations}

GBM, glioblastoma multiforme; RTKs, Receptor tyrosine kinases; MVD, microvascular density; vWF, von Willebrand factor.

\section{Competing interests}

The author(s) declare that they have no competing interests.

\section{Authors' contributions}

LFW, EF and JJ carried out the Immunohistochemical studies. AY and FR participated in the design of the study and performed the statistical analysis. AP and HXA partic- ipated the evaluation of analysed parameters and tumor pathological characteristics. REC conceived of the study and participated in the design and coordination as well as helped to draft the manuscript. All authors read and approved the final manuscript.

\section{Acknowledgements}

We are very grateful to our technicians, Mrs. B. Kleb, H. Geißel and R.

Wassmuth for their expert technical assistance.

\section{References}

I. Ohgaki H, Kleihues P: Population-based studies on incidence, survival rates, and genetic alterations in astrocytic and oligodendroglial gliomas. I Neuropathol Exp Neurol 2005, 64:479-489.

2. Reifenberger G, Collins VP: Pathology and molecular genetics of astrocytic gliomas. J Mol Med 2004, 82:656-670.

3. Zhu Y, Parada LF: The molecular and genetic basis of neurological tumours. Nat Rev Cancer 2002, 2:616-626.

4. Schlessinger J, Ullrich A: Growth factor signaling by receptor tyrosine kinases. Neuron 1992, 9:383-39l.

5. van der Geer P, Hunter T, Lindberg RA: Receptor protein-kinases and their signal transduction pathways. Annu Rev Cell Biol 1994, I0:25 |-337.

6. Flanagan JG, Vanderhaeghen P: The ephrins and Eph receptors in neural development. Annu Rev Neurosci 1998, 2 I:309-345.

7. Holder N, Klein R: Eph receptors and ephrins: effectors of morphogenesis. Development 1999, I 26:2033-2044.

8. Kullander K, Klein R: Mechanisms and functions of Eph and ephrin signaling. Nat Rev Mol Cell Biol 2002, 3:475-486.

9. Pasquale EB: Eph receptor signalling casts a wide net on cell behaviour. Nat Rev Mol Cell Biol 2005, 6:462-475.

10. Tessier-Lavigne M: Eph receptor tyrosine kinases, axon repulsion, and the development of topographic maps. Cell 1995, 82:345-348.

II. Winslow JW, Moran P, Valverde J, Shih A, Yuan JQ, Wong SC, Tsai SP, Goddard A, Henzel WJ, Hefti F, Beck KD, Caras IW: Cloning of $A L-I$, a ligand for an Eph-related tyrosine kinase receptor involved in axon bundle formation. Neuron 1995, 14:973-981.

12. Wang HU, Anderson DJ: Eph family transmembrane ligands can mediate repulsive guidance of trunk neural migration and motor axon outgrowth. Neuron 1997, I 8:383-396.

13. Martinez A, Soriano E: Functions of ephrin/Eph interactions in the development of the nervous system: emphasis on the hippocampal system. Brain Res Brain Res Rev 2005, 49:2 I I-226.

14. Lemke G: A coherent nomenclature for Eph receptors and their ligands. Mol Cell Neurosci 1997, 9:331-332.

15. Holland SJ, Gale NW, Mbamalu G, Yancopoulos GD, Henkemeyer M, Pawson T: Bidirectional signaling through the EPH-family receptor Nuk and its transmembrane ligands. Nature 1996, 383:722-725.

16. Davis S, Gale NW, Aldrich TH, Maisonpierre PC, Lhotak V, Pawson T, Goldfarb M, Yancopoulos GD: Ligands for EPH-related recep- 
tor tyrosine kinases that require membrane attachment or clustering for activity. Science 1994, 266:816-819.

17. Bundesen LQ, Scheel TA, Bregman BS, Kromer LF: Ephrin-B2 and EphB2 regulation of astrocyte-meningeal fibroblast interactions in response to spinal cord lesions in adult rats. J Neurosci 2003, 23:7789-7800.

18. Nakada M, Niska JA, Tran NL, McDonough WS, Berens ME: EphB2/ R-Ras signaling regulates glioma cell adhesion, growth, and invasion. Am J Pathol 2005, 167:565-576.

19. Nakada M, Niska JA, Miyamori H, McDonough WS, Wu J, Sato $H$, Berens ME: The Phosphorylation of EphB2 Receptor Regulates Migration and Invasion of Human Glioma Cells. Cancer Res 2004, 64:3179-3185.

20. Erber R, Eichelsbacher U, Powajbo V, Korn T, Djonov V, Lin J, Hammes HP, Grobholz R, Ullrich A, Vajkoczy P: EphB4 controls blood vascular morphogenesis during postnatal angiogenesis. $E M B O$ J 2006, 25:628-64।

21. Nakada M, Drake KL, Nakada S, Niska JA, Berens ME: Ephrin-B3 Ligand Promotes Glioma Invasion through Activation of Racl. Cancer Res 2006, 66:8492-8500.

22. Hatano M, Eguchi J, Tatsumi T, Kuwashima N, Dusak JE, Kinch MS, Pollack IF, Hamilton RL, Storkus WJ, Okada H: EphA2 as a gliomaassociated antigen: a novel target for glioma vaccines. Neoplasia 2005, 7:717-722.

23. Liu FH, Park PJ, Lai W, Maher E, Chakravarti A, Durso L, Jiang X, Yu Y, Brosius A, Thomas M, Chin L, Brennan C, DePinho RA, Kohane I, Carroll RS, Black PM, Johnson MD: A genome-wide screen reveals functional gene clusters in the cancer genome and identifies EphA2 as a mitogen in glioblastoma. Cancer Res 2006, 66: 10815-10823.

24. Taneja R, Thisse B, Rijli FM, Thisse C, Bouillet P, Chambon P: The expression patter of the mouse receptor tyrosine kinase gene MDKI is conserved through evolution and requires Hoxa-2 for rhombomere-specific expression in mouse embryos. Dev Biol 1996, 177:397-4I2.

25. Ciossek T, Millauer B, Ulrich A: Identification of alternatively spliced mRNAs encoding variants of MDKs, a novel receptor tyrosine kinase expressed in the murine nervous system. Oncogene 1995, 10:97-108.

26. Valenzuela DM, Rojas E, Griffiths JA, Compton DL, Gisser M, Ip NY, Goldfarb M, Yancopoulos GD: Identification of full length and truncated forms and Ehk-3, a novel member of the Eph receptor tyrosine kinase family. Oncogene 1995, I0:1573-1580.

27. Ciossek T, Ullrich A, West E, Rogers JH: Segregation of the receptor EphA7 form its tyrosine kinase-negative isoform on neurons in adult mouse brain. Molecular Brain Res 1999, 74:23I-236.

28. Rogers JH, Ciossek T, Ullrich A, West E, Hoare M, Muir EM: Distribution of the receptor EphA7 and its ligands in development of the mouse nervous system. Molecular Brain Res 1999, 74(I-2):225-230.

29. Holmberg J, Clarke DL, Frisén J: Regulation of repulsion versus adhesion by different splice forms of an Eph receptor. Nature 2000, 408:203-206

30. Figueroa JD, Benton RL, Velazquez I, Torrado AI, Ortiz CM, Hernandez CM, Diaz IJ, Magnuson DS, Whittemore SR, Miranda JD: Inhibition of EphA7 up-regulation after spinal cord injury reduces apoptosis and promotes locomotor recovery. I Neuroscience Res 2006, 84(7): |438-|45|.

31. Depaepe V, Suarez-Gonzalez N, Dufour A, Passante L, Gorski JA, Jones $K R$, Ledent $C$, Vanderhaeghen P: Ephrin signaling controls brain size by regulation apoptosis of neural progenitors. Nature 2005, 435: I 244- 1250 .

32. Weidner N, Semple JP, Welch WR, Folkman J: Tumor angiogenesis and metastasis-correlation in invasive breast carcinoma. N Engl J Med I99I, 324: I-8.

33. Wykosky J, Gibo DM, Stanton C, Debinski W: EphA2 as a novel molecular marker and target in glioblastoma multiforme. Mol Cancer Res 2005, 3:54I-55I.

34. Walker-Daniels J, Coffman K, Azimi M, Rhim JS, Bostwick DG, Snyder P, Kerns BJ, Waters DJ, Kinch MS: Overexpression of the EphA2 tyrosine kinase in prostate cancer. Prostate 1999, 41:275-280.

35. Kinch MS, Moore MB, Harpole DH Jr: Predictive Value of the EphA2 Receptor Tyrosine Kinase in lung cancer recurrence and survival. Clin Cancer Res 2003, 9:613-618.
36. Miyazaki T, Kato H, Fukuchi M, Nakajima M, Kuwano H: EphA2 overexpression correlates with poor prognosis in esophogeal squamous cell carcinoma. Int J Cancer 2003, 103:657-663.

37. Easty DJ, Hill SP, Hsu MY, Fallowfield ME, Florenes VA, Herlyn M, Bennett DC: Up-regulation of ephrin-Al during melanoma progression. Int J Cancer 1999, 84:494-50I.

38. Thaker PH, Deavers M, Celestino J, Thornton A, Fletcher MS, Landen CN, Kinch MS, Kiener PA, Sood AK: EphA2 expression is associated with aggressive features in ovarian carcinoma. Clin Cancer Res 2004, 10:5I45-5I50.

39. Wu D, Suo Z, Kristensen GB, Li S, Troen G, Holm R, Nesland JM: Prognostic value of EphA2 and EphrinA-I in squamous cell cervical carcinoma. Gynecol Oncol 2004, 94:3I2-3I9.

40. Zelinski DP, Zantek ND, Stewart JC, Irizarry AR, Kinch MS: EphA2 overexpression causes tumorigenesis of mammary epithelial cells. Cancer Res 200I, 6I:230I-2306.

41. Nakamura R, Kataoka H, Sato N, Kanamori M, Ihara M, Igarashi $H$, Ravshanov S, Wang YJ, Li ZY, Shimamura T, Kobayashi T, Konno H, Shinmura K, Tanaka M, Sugimura H: EPHA2/EFNAI expression in human gastric cancer. Cancer Sci 2005, 96:42-47.

42. Kataoka $\mathrm{H}$, Igarashi $\mathrm{H}$, Kanamori $M$, lhara $M$, Wang JD, Wang $\mathrm{YJ}, \mathrm{Li}$ ZY, Shimamura T, Kobayashi T, Maruyama K, Nakamura T, Arai H, Kajimura M, Hanai $H$, Tanaka M, Suqimura $H$ : Correlation of EphA2 overexpression with high microvessel count in human primary colorectal cancer. Cancer Sci 2004, 95: | 36- | 4 |.

43. Hafner C, Schmitz G, Meyer S, Bataille F, Hau P, Langmann T, Dietmaier W, Landthaler M, Vogt T: Differential gene expression of Eph receptors and ephrins in benign human tissues and cancers. Clin Chem 2004, 50:490-499.

44. Surawska H, Ma PC, Salgia R: The role of ephrins and Eph receptors in cancer. Cytokine Growth Factor Rev 2004, 1 5:419-433.

45. Nakanishi H, Nakamura T, Canaani E, Croce CM: ALLI fusion proteins induce deregulation of EphA7 and ERK phosphorylation in human acute leukemias. Proc Natl Acad Sci USA 2007, 104: 14442-14447.

46. Wang JD, Kataoka H, Suzuki M, Sato N, Nakamura R, Tao H, Maruyama K, Isogaki J, Kanaoka S, Ihara M, Tanaka M, Kanamori M, Nakamura T, Shinmura K, Sugimura H: Downregulation of EphA7 by hypermethylation in colorectal cancer. Oncogene 2005, 24:5637-5647.

47. Mitelman F, Johansson B, Mertens F: Mitelman Database of Chromosome Aberrations in Cancer. [http://cgap.nci.nih.gov/Chro mosomes/Mitelman].

48. Noren NK, Foos G, Hauser CA, Pasquale EB: The EphB4 receptor suppresses breast cancer cell tumorigenicity through an AblCrk pathway. Nat Cell Biol 2006, 8:8I5-825.

49. Xia G, Kumar SR, Masood R, Koss M, Templeman C, Quinn D, Zhu S, Reddy R, Krasnoperov V, Gill PS: Up-regulation of EphB4 in mesothelioma and its biological significance. Clin Cancer Res 2005, I I:4305-43 I5.

50. Davis S, Gale NW, Aldrich TH, Maisonpierre PC, Lhotak V, Pawson T, Goldfarb M, Yancopoulos GD: Ligands for EPH-related receptors that require membrane attachment or clustering for activity. Science 1994, 266:816-819.

51. Dawson DW, Hong JS, Shen RR, French SW, Troke JJ, Wu YZ, Chen SS, Gui D, Regelson M, Marahrens Y, Morse HC III, Said J, Plass C, Teitell MA: Global DNA methylation profiling reveals silencing of a secreted form of EphA7 in mouse and human germinal center B-cell lymphomas. Oncogene 2007, 26:4243-4252.

52. Brantley DM, Cheng N, Thompson EJ, Lin Q, Brekken RA, Thorpe PE, Muraoka RS, Cerretti DP, Pozzi A, Jackson D, Lin C, Chen J: Soluble Eph $A$ receptors inhibit tumor angiogenesis and progression in vivo. Oncogene 2002, 21:701 I-7026.

53. Gale NW, Yancopoulos G: Growth factors acting via endothelial cell specific receptor tyrosine kinases: VEGFs, angiopoietins, and ephrins in vascular development. Genes 1999 13(9): 1055-1066.

54. Yancopoulos GD, Davis S, Gale NW, Rudge JS, Wiegand SJ, Holash J: Vascular-specific growth factors and blood vessel formation. Nature 2000, 407:242-248.

55. Ogawa K, Pasqualini R, Lindberg RA, Kain R, Freeman Al, Pasquale EB: The ephrin-AI ligand and its receptor, EphA2, are expressed during tumor neovascularization. Oncogene 2000, 19:6043-6052. 
56. Mitra AP, Datar RH, Cote RJ: Molecular Pathways in Invasive Bladder Cancer: New Insights Into Mechanisms, Progression, and Target Identification. J Clin Oncol 2006, 24:5552-5564.

57. Chantrain CF, DeClerck YA, Groshen S, McNamara G: Computerized quantification of tissue vascularization using high-resolution slide scanning of whole tumor sections. J Histochem Cytochem 2003, 5I:I5I-I58.

58. Uzzan B, Nicolas P, Cucherat M, Perret GY: Microvessel density as a prognostic factor in women with breast cancer: a systematic review of the literature and meta-analysis. Cancer Res 2004, 64:294I-2955.

59. Preusser M, Heinzl H, Gelpi E, Schonegger K, Haberler C, Birner P, Marosi C, Hegi M, Gorlia T, Hainfellner JA, European Organization for Research and Treatment of Cancer Brain Tumor Group: Histopathologic assessment of hot-spot microvessel density and vascular patterns in glioblastoma: Poor observer agreement limits clinical utility as prognostic factors: a translational research project of the European Organization for Research and Treatment of Cancer Brain Tumor Group. Cancer 2006, 107:162-170.

60. Korkolopoulou P, Patsouris E, Kavantzas N, Konstantinidou AE, Christodoulou P, Thomas-Tsagli E, Pananikolaou A, Eftychiadis C, Pavlopoulos PM, Angelidakis D, Rologis D, Davaris P: Prognostic implications of microvessel morphometry in diffuse astrocytic neoplasms. Neuropathol Appl Neurobiol 2002, 28:57-66.

\section{Pre-publication history}

The pre-publication history for this paper can be accessed here:

http://www.biomedcentral.com/1471-2407/8/79/prepub

Publish with Biomed Central and every scientist can read your work free of charge

"BioMed Central will be the most significant development for disseminating the results of biomedical research in our lifetime. "

Sir Paul Nurse, Cancer Research UK

Your research papers will be:

- available free of charge to the entire biomedical community

- peer reviewed and published immediately upon acceptance

- cited in PubMed and archived on PubMed Central

- yours - you keep the copyright 